\title{
CDNF- $800980--43$
}

CONSTRUCTION PROGRAM FOR A IARGE SUPERCONDUCTING MHL MAGNET SYSTEM

AT THE

COAL-FIRED FLOW FACILITY

by

S.-T. Wang, I. Genens, J. Gonczy, H. Ludwig, M. Lieberg, E. Kraft, D. Gacek, Y.-C. Huang, and C.-J Chen

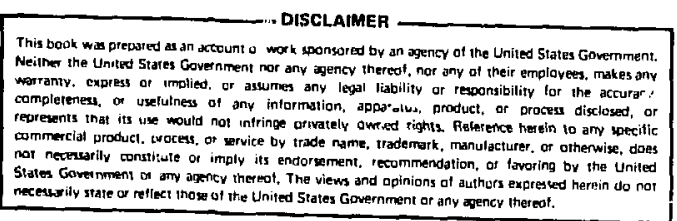

Prepared for

Applied Superconductivity Conference

Santa Fe, New Mexico

September 29, 1980 - October 3, 1980

and

IEEE Transactions on Magnetics

ARGONNE MATIONAL LABORATORY, ARGONNE, ILLINOLS

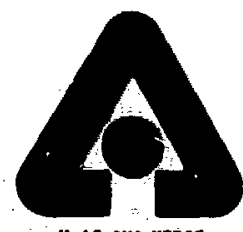

Operated under Contract $W-31-109-E n g-38$ for the

U. S. DEPARTMENT OF ENERGY 


\title{
CONSTRUCTION PROGRAY EOR A LAREE SUPERCONDUCTING MAD MGNET SYSTEX AT THE COAL-FIRED FLON FACILITY*
}

\author{
S.-T. Wang, Z. Genens, J. Gonezy, H. Ludulg, X. Lieberg, \\ E. Kraft, D. Gacek, Y,-C. Buning and C.-J. Chen \\ Argonne National Laboratory \\ 9700 South Cass Avenue \\ Argonne, IL 60439
}

\section{Summary}

The Argonne Nat1onal Laboratory has deatgped and Ia constructing a 6 T large aperture auperconducting whil magnet for use in the Conl-Fired Plow Fac1lity (CFFF) at the Untversity of Tannessne Space Institute (UTSI) at Tullahowe, Tennessee. The ragnet gystem conslatg of the superconducting magnet, a agnet pover supply, an Integraced Instrumentation for operation, concrol and protection, and a couplete cryogentc

facillcy Including a CII Model 2800 hellum refrigerator/ 11quefier wh two compressors, hellu gas hindling syacen and a 7500 liter liquid hallum dewar. The complete syatem w111 be teated at Argonne, II tn 1981. This papar first briefly reviews the wognet design. Second, the coll fabrication programs are deacribed in detall.

\section{Magnet Design ${ }^{1}$}

The magnet consists of fourteen concentric layera with a shorter coll (coll lager ko. 1) close to the bore cube. Thts generated a linear tapered fleld with a maximum on-axis intensity of $6 \mathrm{~T}$. The cefl shape is a circular saddle which will support the hoop stress of

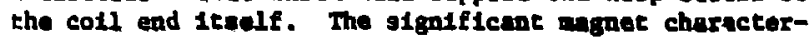
Iatles are listed in Table I. The CFFE had angnet configuracion, with field profile, and cryontat detalls are show in Figa. 1 and 2 respectively.

The conductor 1s a soldered ausembly of a suparm conducting cable wre of $\mathrm{Mb}-48 \mathrm{TI}$ II superconducting composite wire that fits into the longltudinal groove of OPHC copper stabllizer. Three grades of conductor are used: Grede $A$ wt $a 4.2 \mathrm{~K}$ ahort saple criten current of $4400 \mathrm{~A}$ at $7.5 \mathrm{~T}$; Grade $\mathrm{B}, 4400 \mathrm{~A}$ at $6.5 \mathrm{I}$; and Grade C, $4400 \mathrm{~A}$ at $4.5 \mathrm{~T}$. The operating potat is $3670 \mathrm{~A}$ at $4.2 \mathrm{~K}$ with a fleld margin of $0.5 \mathrm{I}$ for ench grade of conductor. All conductor thes a height of $3.1 \mathrm{~cm}$ with coaductor thickness varying according to the fleld grades. The surface of superconducting cable is recessed below scablliear surfece by $0.76 \mathrm{~m}$, thus forming a longitudinal cooling chinnel for the cable. Since it is difficule to predict the atze of the vorat disturbance the magnat will ancouncer, tho sonductor is destgned baced on stendy state exyostablisty. The coll

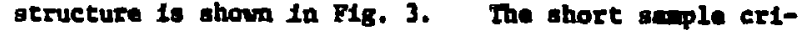
cical current, the atnime propagating current, the recovery current, the operating point and the land line are shown in F1g. 4. Also shown is the turn-to-turn insulation wich is a pultruded tibargless atrip with keystone crosp-gection. It is punched in a tiphbont11ke pattern for providing about 307 cooling on both of the conductor broed Eaces.

The conductor in the high field croes section exerts a burst force of $30,180 \mathrm{kgf} / \mathrm{cm}$ outward uhich is concalned by girder rluge ande of cating $316 \mathrm{~L}$ statnLess steel axe segarate and 2219-287 aluitaw t1e plates (aee Fig. 1). A cleping torcs of $24,287 \mathrm{kgf} / \mathrm{co}$ purhe the two coll halves of the aganet together. The decentaring force of 219,500 kgf, reamlelng frow the asymatric field dietribution, is suppored by the end

Whak supported by the O.S. Departeant of Energy flange at the high field end and by a step in the bore tube.

The cryostat configuration 1s shown in F1g. 1. The cryostat consiste of a hellue vessel, a liquid nitrogen coolad shield and a vacuum veasal serving as a preasure veseel and a support structure for cold wass. Steady atate heat fluxes to the hellum veasel and the thermal. shield have been minimized by the use of multilayer 1nsulacton around the nicrogen shleld and hellum vessel. and by use of low heat leak support scructures. The stendy state hoat flux to the hellum vessel is $14.0 \mathrm{~W}$; 1.e. $19.6 \mathrm{~L} / \mathrm{h}$. The steady state flux to the thermal ahleld 10 $179 \mathrm{H} ; 1.0 .4 .3 \mathrm{~L} / \mathrm{h}$ boll-off.

\section{Co11 Fabricacion}

To provide for efficlent and accurate construction of the colls, a eervowechanized winding wachine vas developed as shown in F1g. 5. The Micarta coil form 18 factened to a unding drum which is supported by a turntable. As the table cotates about 1ts vertical axis, the drum revolves about its horlzontal axe. volded plyood forms are uned to provide the required radius of the vinding drum. Four sets of hold-down fixtures are ured to anchor eech conductor widing as it if bent around the winding drum to form the saddle co11s. Mylon straps and supporting aras which are pnowatcally powred are ueed to suppore the conductor at stralghe reglon. Figure 5 shows a coll winding for coll layer io. 7 .

\section{Conductor Splice}

During the coll elading, different flald grades of conductors ace used. To perform these joluts, resistence welder ${ }^{2}$ wal ured to wid the stablilizer of one grade to one end of prefabricated OFBC transition stabillzar. Likewlae, the ocher end of te vas weldad vith a tabilizer of another fleld grade. The excese copper In thece valds wee rewoved and the superconducting cablea were lapped jolnted over the transition atab1112er. During the coll sastubly, splices are ande to connoce the coll halves In the aem layer and to connece the colls In adjecent layars. Thane ara softcolder Iapped folnte with copper riveta bondisg as relnforchint.

\section{Co11 Angembly}

As thoun in F1g. 6, the coll ansembly starta by flree Inotalling the bore cube mandral to the boze tube. The assanbly is then lifted onto the powar zolls. the bore tube 10 Inculated sth an epoxy fiberglase cylinder with groover anchined for liquid hellu perforation as show in P1g. 7.

Each layer coll aneaubly beging by Iffting a pair of colls onto the asscombly tube. Then the coll is comprovesed radially by a set of stainleas ateel bunds. Parting jacks are used to Jack-apart the gape betreen the tro halves parforutog the astruthal coupression. Hearte apacare of proper undth are placed between the two halves. A sat of taflatable yellow bago are nov inetallad between the stainless seeal bands to execute the fioel radial precomptaseston as sinown in F1g. B. 


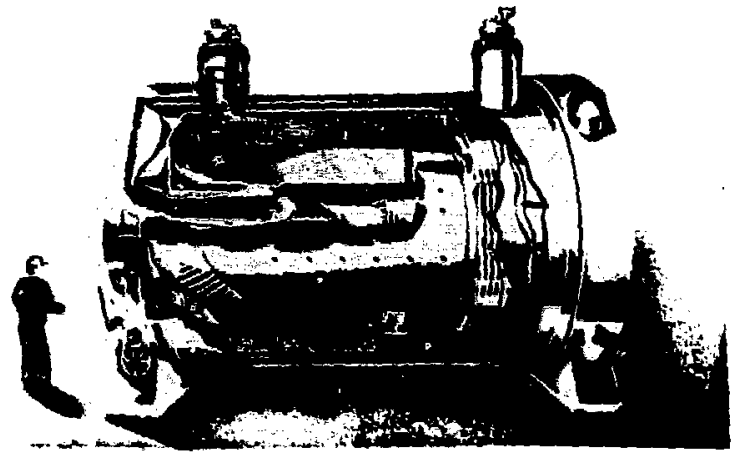

Fig. 1 CFFE MAD Magnet Configuration
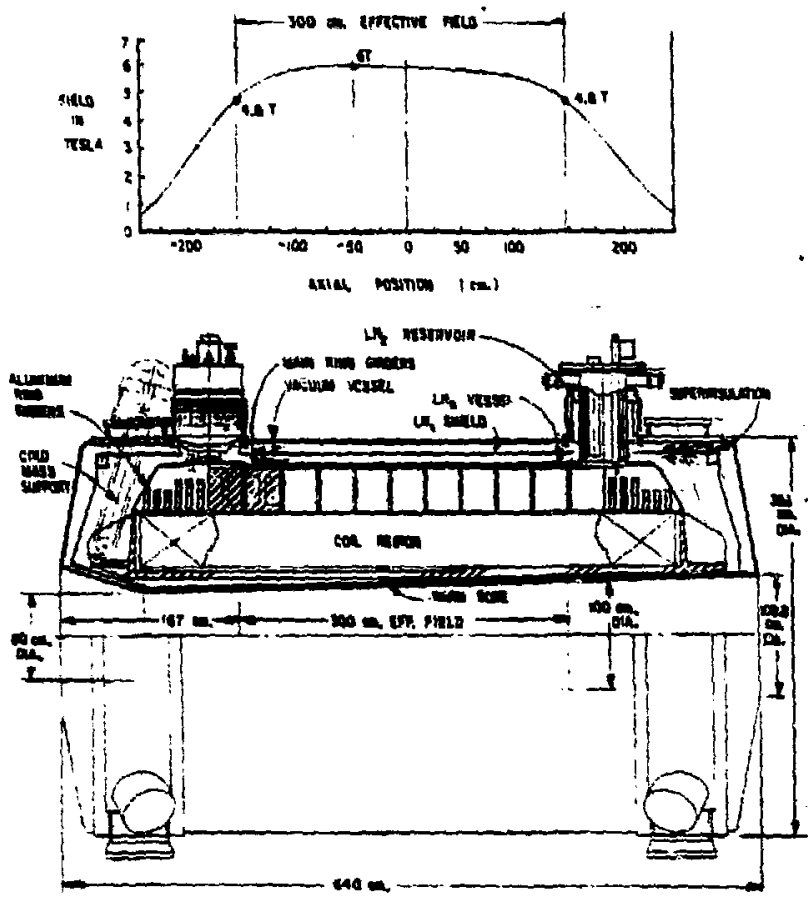

Fig. 2 m Field Profile and Cryostat Detafls

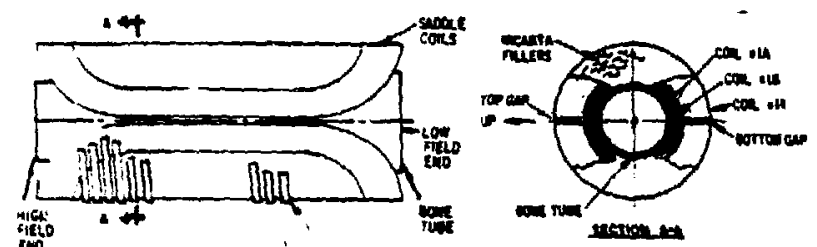

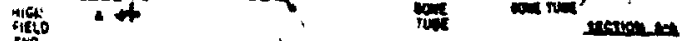

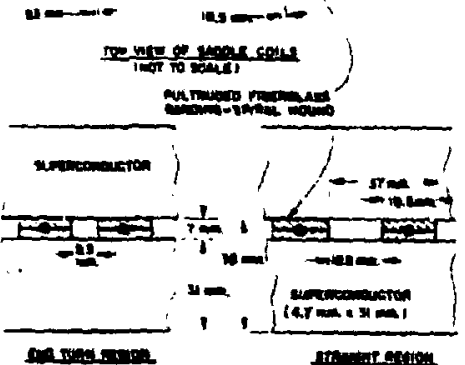

wra-rovintemente
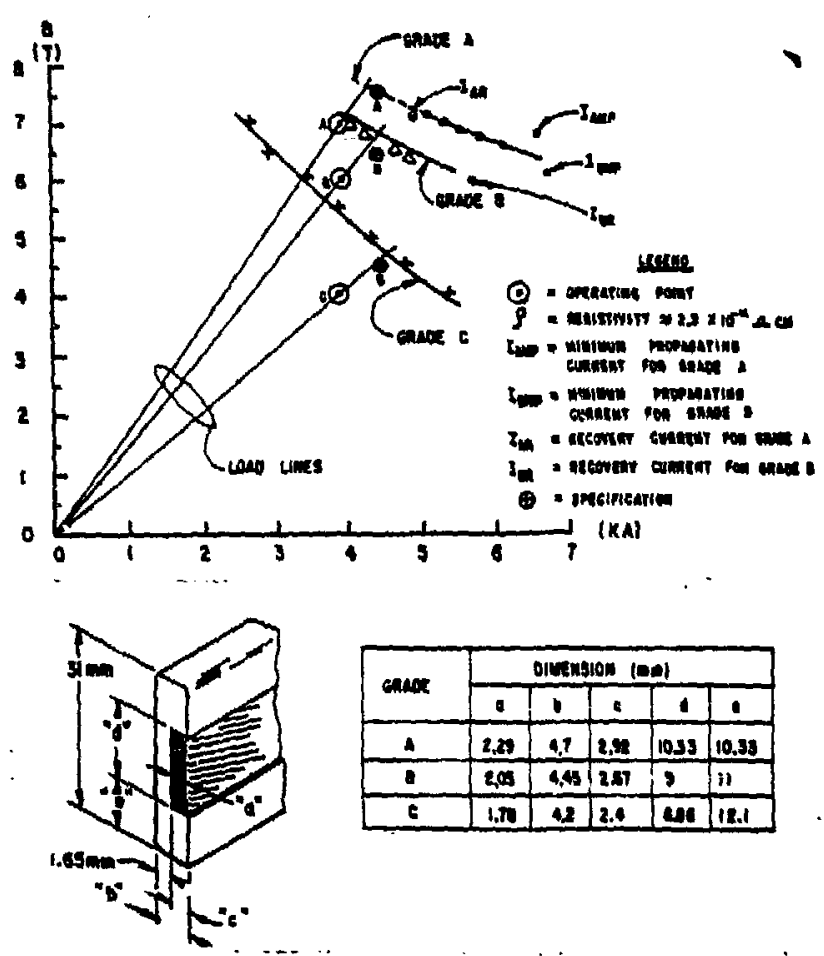

\begin{tabular}{|c|c|c|c|c|c|}
\hline \multirow{2}{*}{ enes } & \multicolumn{5}{|c|}{ ointinstion (ne) } \\
\hline & 9 & 1 & 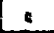 & 1 & 1 \\
\hline 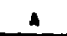 & $2 . n$ & 4.7 & $2, n$ & 10.33 & 10.38 \\
\hline - & 2,0 & 4,4 & 251 & 1 & (i) \\
\hline E & $1, \pi$ & 42 & 2.4 & 4 & 12.1 \\
\hline
\end{tabular}

Fig. 4 Conductor Short Sample Characteristies

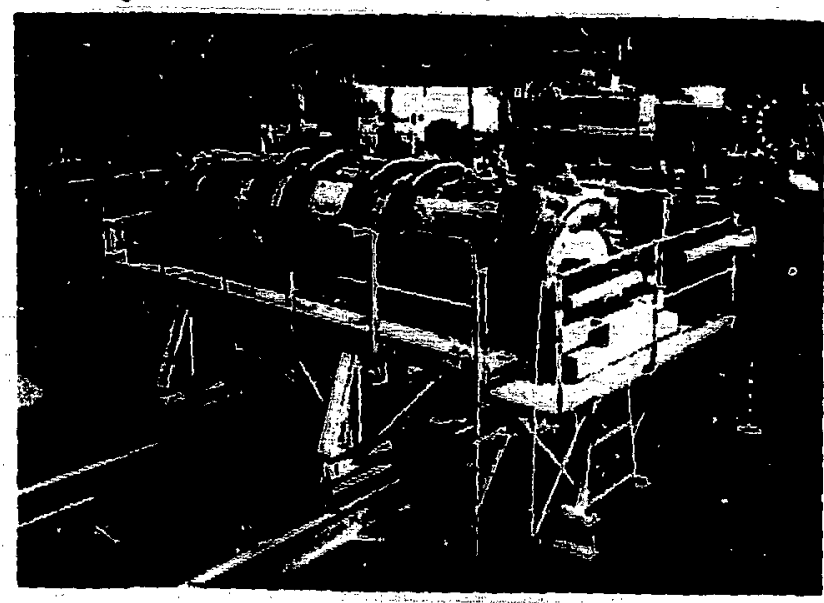

P1g. 5 Coll HIadiag Operation

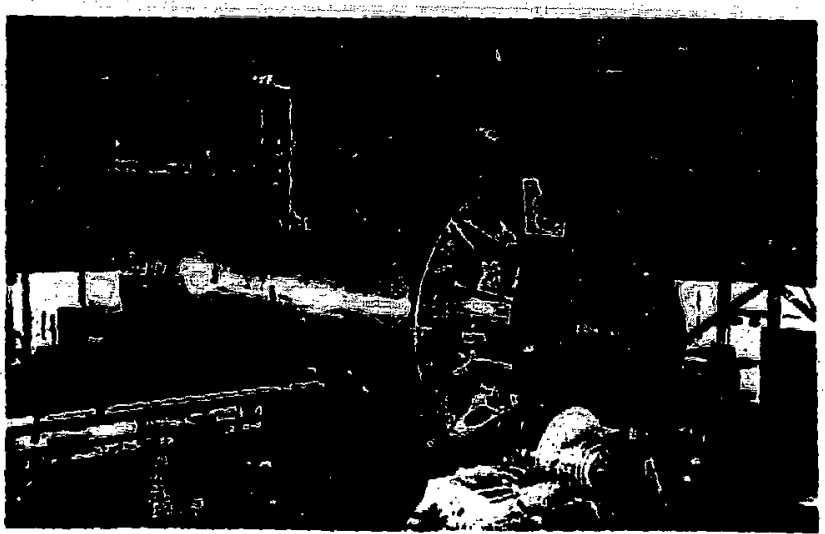

F1g. 6 Hore Tube Installarion on Power Rolls 
Conductor splices are made, then follows the inatallation of coll end f11lers and the application of $A+B$ epoxy to fill the volds at coll ends. Spiral permenent bandings of pultruded fiberglaes, 18.5 wn wide $x 7$ m.m thick, are finally installed prograssivaly to replace all the temporary strape leaving a 18.5 spacing between two banda in the stralght conductor region and $6.2 \mathrm{~min}$ in the coli and reglon. The banding tenaion uged is about $2000 \mathrm{~kg}$. This final compression solidly secures the coll layer against the previous layer and tolerates little buildup within the winding, thus restraintas any movement of the coll and provides layerto-layer soparation and adequate liquid hellum flow pasases. Flgure 9 showe the bandings for the cot1 layer io. 6.

\section{Aasembly of Reng Girders and Cryostat}

F1gure 10 shows the step-by-gtep procedure for the assembly of the ring girders and cryostat.

Once the fourteen layers of colls are secured to the bore tube, a gertes of eleven main girder riage w11l be positioned over the stralght conductor regton to resiat agatnat the burat forces from the vinding. In the coll end region four smaller and ringa will be Inatalled. These girders will be clemped sightly agalnat a surface of fiberglase rings which were inatalled to provide a machined gurface with curvature matching that of the ring 81rder.

The coll assembly is now ready to be sealed in its hellum vessel. A tower assembly is then added to house the many wires and piping that would be used to communicate with the magnet.

The attrogen coolant is carried by copper tubing soldered to the valls of the shield which is made of acadnless steel to eliminace the risk of shield collapse should the magnet have a rapld dischnrge. Nore superinsulation of the aluminized Mylar 10 added to reduce the radiation load on the nitrogen sbield. The enctre assembly is then placed Into an Insulating vacuum. The magnet Is nov ready for the installation of the assembly of magnet rarm bore tube and the Inner liquid nierogen shield. The final assembly is the Inatallation of end shleld and the end caps of the vacuum vessel.

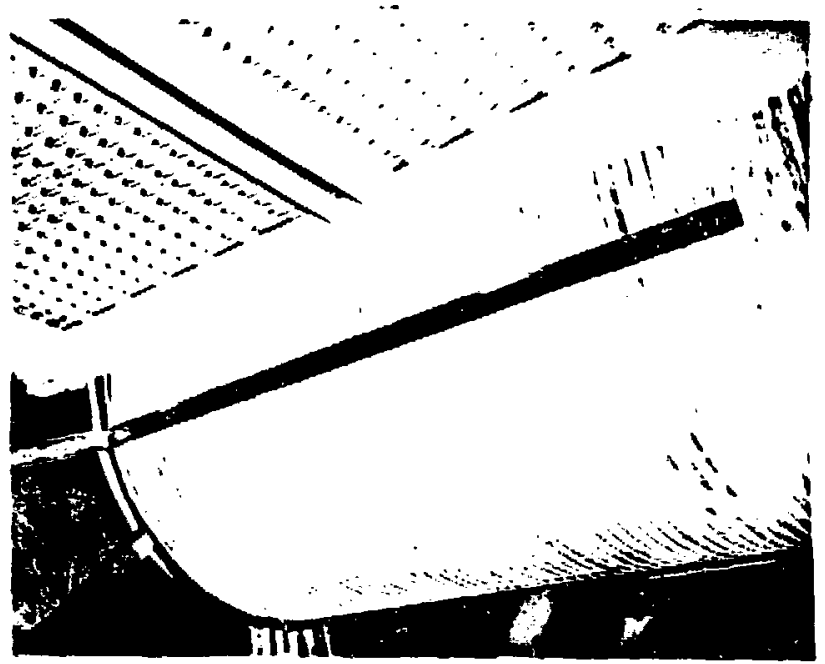

F1g. 7 Bore Tube Insulation
Table I

CEFF SCMS Yagnet Paramaters

I. Man Relsted Paramaters

Mifn on-axis Field

Inlet $4.8 \mathrm{~T}$, peak $6 \mathrm{~T}$, Outlet $4.8 \mathrm{~T}$

F1eld Taper

Liner taper with a gradient of $0.2 \mathrm{~T} / \mathrm{m}$

II. Magnec Co11 Character1ac1cs.

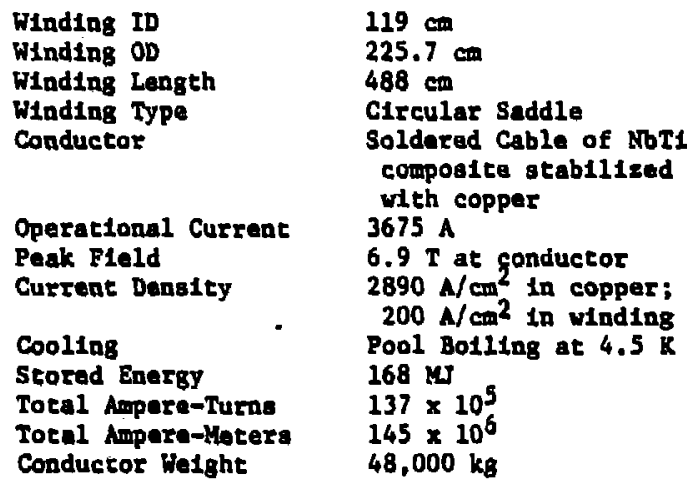

III. Cryostat Paramaters

\begin{tabular}{|c|c|}
\hline $\begin{array}{l}4.2 \mathrm{~K} \text { Cold Mass Weight } \\
4.2 \mathrm{~K} \text { Cold Mass Dimen. } \\
\text { Liquid Hellum Inventory } \\
\text { Hest Leak to LRe } \\
\text { Vacuum Veasel Weight } \\
\text { Vacuum Vessel Dimen. } \\
\text { Total Magnat Ue1ght }\end{array}$ & 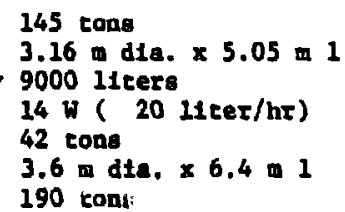 \\
\hline
\end{tabular}

\section{Aclonouledroments}

The authors would like to acknowledge the concributiona of J. Rotora, B. PhIIl1pe, D. Sapp, W. Sajdak, E. Johanson, K. Macaya, and J. Bof fman of the Argonne Nac1onal Laboratory; the contribuctors of $T$. Takag1 of the Tolyyo Untversity; and S. Stoy of Cryogenic Consultants.

\section{Beferencee}

1. "The Design of a Superconducting cho Magnet for the Coal-F1red Flow Eacility at the Univeralty of Tennesgee," S,-T. Mang, L. R. Turzer, L. E. Genens, J. Hoffun, W. Pelczarsk1, J. Gonczy, H. Ludulg, R. C. N1emann, K. Mataya, and E. Kraft, Advances in Cryogentc Englneering, Vol. 25, (1980).

2. Machanical and Rlectrical Properties of Resletance Welds at Cryogentc Temperature," S.-T. Wang, H. Ludwtg, Advances in Cryogenic Engtneertng, Val. 25 (1980). 


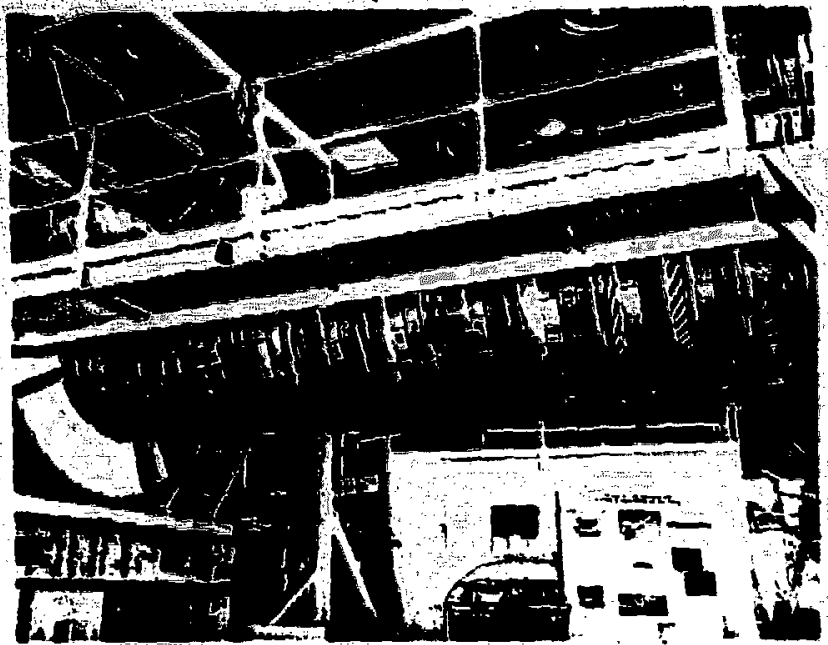

F1g. 8 Coll Precompreselon

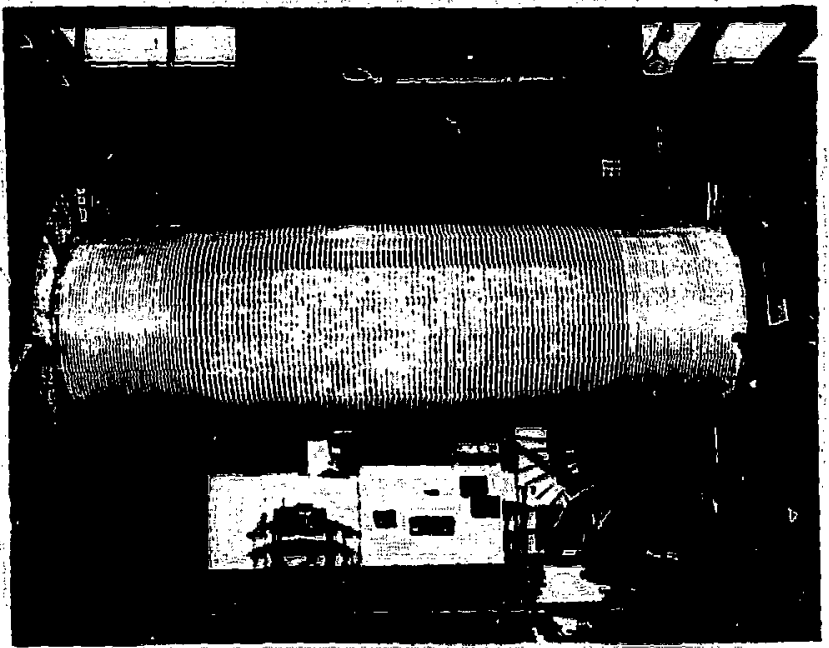

718. 9 Cotl Banding
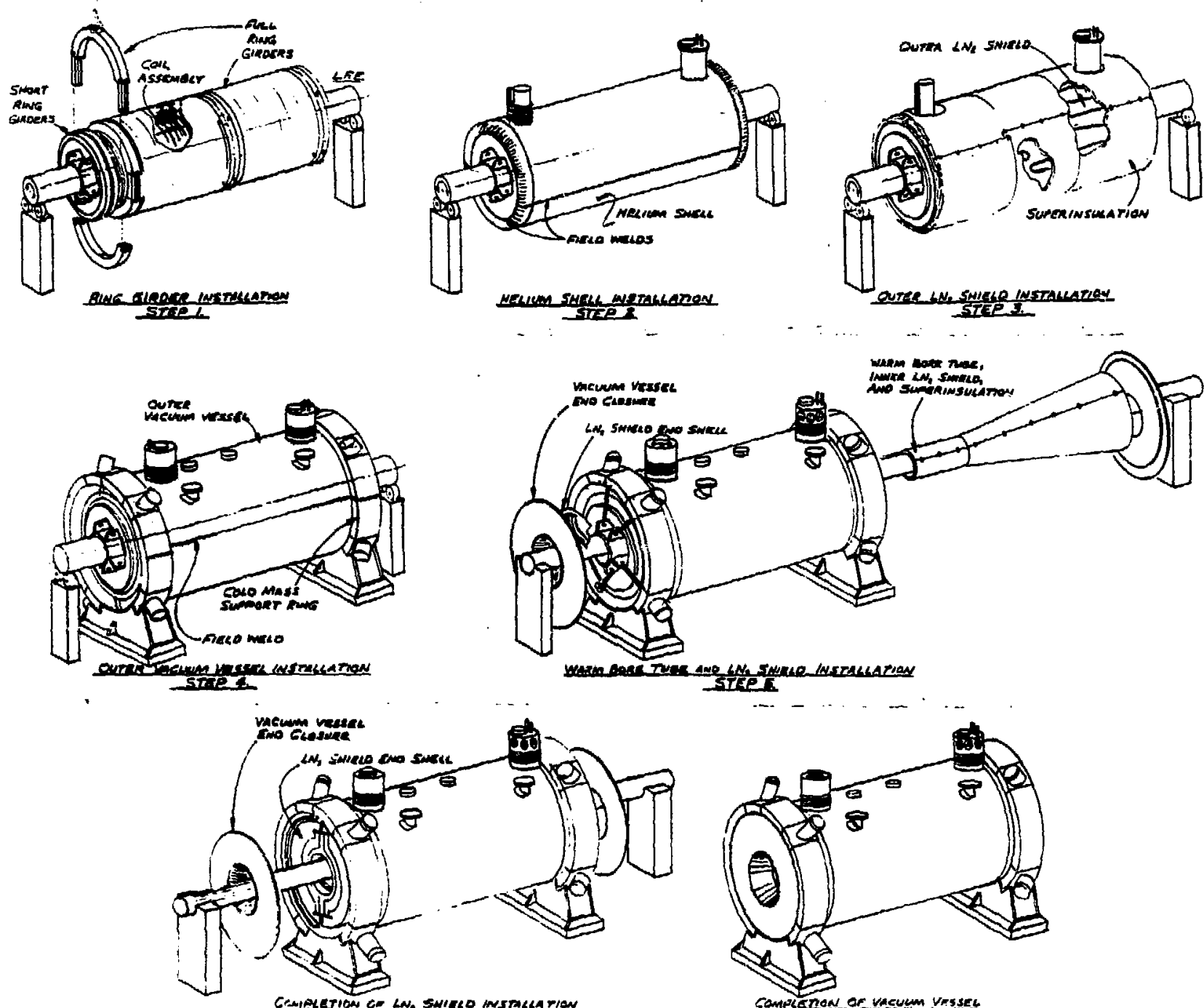
STEPS:

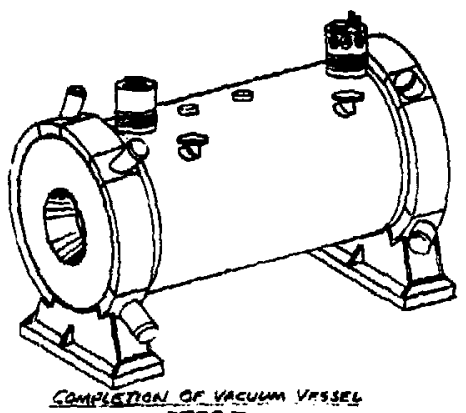
sTEe

Fig. 10 Schemstic of Rlag Girder and Cryostat Assembly 